\title{
DIURNAL BIRD VISITING OF Caryocar brasiliense Camb. IN CENTRAL BRAZIL
}

\author{
MELO, C. \\ Instituto de Biologia, Universidade de Brasília, CEP 70910-900, Brasília, DF, Brazil \\ Correspondence to: Celine Melo, Rua Feliciano de Morais, 2743, Bairro Custódio Pereira, CEP 38405-188, \\ Uberlândia, MG, Brazil, e-mail: celinemelo@bol.com.br \\ Received January 21, 2000 - Accepted May 5, 2000 - Distributed May 31, 2001
}

(With 2 figures)

\begin{abstract}
Nectar of nocturnal flowers may be used by diurnal species that occasionally accomplish secondary pollination. Thirteen bird species visited Caryocar brasiliense flowers in central Brazil. There is a temporal separation between nectarivores and non-nectarivores species. Nectarivores birds visited flowers late in the morning, while other species appear earlier. $C$. brasiliense nectar may be an alternative resource to birds visitors during the dry season.
\end{abstract}

Key words: birds, Caryocar brasiliense, nectar, resource.

\section{RESUMO}

\section{Aves diurnas visitando Caryocar brasiliense Camb. no Brasil Central}

O néctar de flores noturnas pode ser utilizado por uma fauna diurna. As flores de Caryocar brasiliense foram visitadas por 13 espécies de aves, no Brasil central. Há uma distribuição temporal entre nectarívoros e não-nectarívoros. Aves nectarívoras concentram suas visitas no final da manhã e à tarde, outras aves, no início da manhã. O néctar de $C$. brasiliense pode ser um recurso alternativo para as aves visitantes na estação seca.

Palavras-chave: aves, Caryocar brasiliense, néctar, recurso.

\section{INTRODUCTION}

Pollination by neotropical bats involves lightcolored nocturnal flowers that release strong, distinct odors (Endress, 1994). According to Rocha et al. (1991), opportunistic diurnal species or secondary pollinators may use nectar produced by nocturnal flowers. Caryocar brasiliense, is visited at night by bats, moths, wasps and ants (Gribel, 1986) and, during the day, by birds, bees, wasps (Gribel, 1986; Rocha et al., 1991), ants, moths and beetles (Rocha et al., 1991). It is self-compatible, but the fruit-set is higher when cross-pollination occurs (Gribel \& Hay, 1993). The objectives of this study were to list diurnal bird visitors of $\mathrm{Ca}$ ryocar brasiliense flowers and evaluate temporal distribution as well as agonistic interactions between birds.

\section{MATERIAL AND METHODS}

Field work was conducted from September 4 to 9, 1999, in Cerrado sensu lato of the Reserva Ecológica do Instituto Brasileiro de Geografia e Estatística $\left(15^{\circ} 45^{\prime} \mathrm{S}\right.$ and $47^{\circ} 48^{\prime} \mathrm{W}$; altitude: $1,000 \mathrm{~m}$ ), Distrito Federal, Brazil. The climate is tropical, with rainy summers and dry winters.

Caryocar brasiliense Camb. (Caryocaraceae), or "Souari Nut", is common in central Brazil, with up to 30 flowers per inflorescence during the second half of the dry season (July-September) in the Distrito Federal. Nectar is produced at a constant rate from the time anthesis starts, between 18:30 and 20:00, until dawn (Gribel \& Hay, 1993).

Three $C$. brasiliense individuals were observed each one on alternate two days, from 6:00 to 10:00 and from 15:30 to 18:00, resulting in 32 hours and 
50 minutes of total observation time, with a $7 \times 25$ binocular. For each visit, the following items were observed and recorded: a) bird species (according to Frisch, 1981, and Grantsau, 1988), b) time of day, c) duration of visit (in seconds) and d) occurrence of agonistic interactions.

In 14 flowers, volume $(0.5 \mathrm{ml}$ syringe $)$ and concentration (refractometer) of nectar were measured between 6:00 and 10:00. During nectar removal, flowers were isolated in paper bags to avoid visits by birds. Percentage of sugar in the nectar was converted to grams per liter. Each milligram of sugar per milliliter of nectar contains four calories (Kearns \& Inouye, 1993).

Chi-square test was used to compare the distribution of birds which main diet is nectar (nectarivores) and main diet is not nectar (non-nectarivores) between 6:00 to $8: 00$ and $8: 00$ to $10: 00$.

\section{RESULTS}

Thirteen species of three families visited $C$. brasiliense, mostly Thraupidae $(59 \% ; n=7)$ (Table 1). Seven species were new records at flowers of this plant (Gribel, 1986; Rocha et al., 1991). Taking into account all species recorded for $C$. brasiliense ( $n=24$ species), the main families were Thraupidae and Trochilidae $(29 \%, \mathrm{n}=7$ each).

The time was recorded for 99 out of 131 visits. In the mornings there were 5.4 visits per hour; while in the afternoons there was only 1.0. Only hummingbirds visited unopened flowers in pre-anthesis during the afternoon $(\mathrm{n}=8)$.

Thraupis sayaca and Amazilia fimbriata visited flowers the most $(25 \% ; \mathrm{n}=30$ and $13 \%$; $\mathrm{n}=$ 16 , respectively). However, mean visit time (in seconds) was longer for Cyanocorax cristatellus, Tachyphonus rufus and Thraupis palmarum (Table 1). Species such as A. fimbriata, Hemithraupis guira and $T$. sayaca, visited flowers often but, briefly.

Visit time was significantly different $\left(\chi^{2}=55.97\right.$; $\mathrm{p}<0.001$ ), for nectarivores and non-nectarivores. The latter visited more between 6:00 and 8:00 while the nectarivores 8:00 and 10:00 (Table 1).

During the morning, the nectar volume/flower/hour decreased, while the mean concentration remained similar (Table 2), but higher than at night (13.4\% for 2.4-19.7 ml/h - Gribel, 1986).
Flowers were visited more from 7:00-8:00, just after the dawn peak of caloric reward. Even though no nectar production between 9:00 and 10:00 was recorded, birds may be using residual nectar (Fig. 1). Permanence time was greater between 7:00 and 9:00, decreasing thereafter (Fig. 2).

Visits by Thraupidae pairs were common (35\% of 23 pairs). C. cristatellus probed flowers in groups of three and six. In spite of the simultaneous presence of individuals of the same or different species, agonistic interactions were rare $(2.5 \%$ of the visits; $\mathrm{n}=3$ ). $T$. rufus attacked $T$. rufus and T. sayaca, and T. furcata attacked an unidentified Trochilidae 2.

Insects, which use the inner, also visit $C$. brasiliense flowers and/or outer part of the calyx, possibly the extra-floral nectaries. None of the birds caught insects.

\section{DISCUSSION}

In the Cerrado, the peak of flowering and fruiting is during the rainy season, but C. brasiliense flowers in the dry season (Oliveira, 1994). Perhaps chiropterophilous flowers blossom in periods of low production of fruits so as to attract more pollen-carrier species (Sazima \& Sazima, 1975, apud Gribel \& Hay, 1993). C. brasiliense may be using this strategy with its primary pollinators and, as a consequence, diurnal floral visitors have benefited. According to Baumgarten (1994), nectar continues to be produced for up to 10 hours after anthesis, and its availability depends on the rate of production and occasional removal by previous visitors. It is also possible that early morning nectar production occurs in flowers with a later anthesis after the evening pattern of most flowers.

Environmental disturbance, seasonality and/ or lack of resources have been suggested as factors that cause modifications in the standard diet (Araújo, 1996; Guix \& Ruiz, 1998). Seasonal resource variations affect the dynamics of nectarivores birds and decrease in nectar availability may cause migration or diet diversification (Feinsinger et al., 1985). Studies have recorded hummingbirds probing non-ornithophilous species (Araújo, 1996; Oliveira, 1998). Similarly, such frugivorous birds as T. sayaca may use $C$. brasiliense as an alternative resource. 
TABLE 1

Temporal distribution of birds visiting Caryocar brasiliense. Mean visits time in seconds.

\begin{tabular}{|c|c|c|c|c|c|c|c|c|c|c|c|c|c|c|c|c|c|c|c|}
\hline \multirow{2}{*}{$\begin{array}{l}\text { Family (3) } \\
\text { Species (13) }\end{array}$} & \multirow{2}{*}{ Diet } & \multicolumn{16}{|c|}{$\operatorname{Time}^{* * * *}$} & \multirow{2}{*}{$\begin{array}{l}\text { Visits } \\
\text { (N) }\end{array}$} & \multirow{2}{*}{ Mean visit time $(\mathbf{N})$} \\
\hline & & 6:00 & $6: 15$ & $6: 30$ & $6: 45$ & $7: 00$ & $7: 15$ & $7: 30$ & $7: 45$ & 8:00 & $8: 15$ & $8: 30$ & $8: 45$ & 9:00 & 9:15 & $9: 30$ & 9:45 & & \\
\hline \multicolumn{20}{|l|}{ Non-passeriformes } \\
\hline \multicolumn{20}{|l|}{ Trochilidae } \\
\hline Thalurania furcata & $\mathrm{N}$ & & & & & & & & & & & & & & & & & 5 & $40.7(4)$ \\
\hline Amazilia fimbriata & $\mathrm{N}$ & & & & & & & & & & & & & & & & & 16 & $46.3(13)$ \\
\hline Eupetomena macroura* & $\mathrm{N}$ & & & & & & & & & & & & & & & & & 1 & $9(1)$ \\
\hline Trochilidae $1 * *$ & $\mathrm{~N}$ & & & & & & & & & & & & & & & & & 2 & $6(1)$ \\
\hline Trochilidae $2 * *$ & $\mathrm{~N}$ & & & & & & & & & & & & & & & & & 2 & $85(2)$ \\
\hline \multicolumn{20}{|l|}{ Passeriformes } \\
\hline \multicolumn{20}{|l|}{ Corvidae } \\
\hline Cyanocorax cristatellus & $\mathrm{O}$ & & & & & & & & & & & & & & & & & 9 & $194(9)$ \\
\hline Thraupidae & & & & & & & & & & & & & & & & & & & \\
\hline Dacnis cayana* & $\mathrm{F}+\mathrm{I}$ & & & & & & & & & & & & & & & & & 8 & $52.4(8)$ \\
\hline Hemithraupis guira* & $\mathrm{F}+\mathrm{I}$ & & & & & & & & & & & & & & & & & 12 & $46.5(9)$ \\
\hline Tangara cayana* & $\mathrm{F}+\mathrm{I}$ & & & & & & & & & & & & & & & & & 6 & $75.5(4)$ \\
\hline Thraupis sayaca* & $\mathrm{F}+\mathrm{I}$ & & & & & & & & & & & & & & & & & 30 & $58.5(26)$ \\
\hline Thraupis palmarum* & $\mathrm{F}+\mathrm{I}$ & & & & & & & & & & & & & & & & & 13 & $109.1(8)$ \\
\hline Tachyphonus rufus & $\mathrm{F}+\mathrm{I}$ & & & & & & & & & & & & & & & & & 14 & $125.1(11)$ \\
\hline Piranga flava & $\mathrm{F}+\mathrm{I}$ & & & & & & & & & & & & & & & & & 3 & $82(2)$ \\
\hline TOTAL & & & & & & & & & & & & & & & & & & 121 & $79.9(95)$ \\
\hline
\end{tabular}


TABLE 2

Mean volume of nectar secreted per hour* (per flower), concentration and calories for Caryocar brasiliense. Mean \pm standard deviation (number of flowers).

\begin{tabular}{|cccc|}
\hline Time of day & Volume $(\mathbf{m l})$ & Concentration $(\%)$ & Calories \\
\hline $06: 00$ & $0.14 \pm 0.20(14)$ & $16.4 \pm 2.7(12)$ & $116.32 \pm 160.62(12)$ \\
$07: 00$ & $0.19 \pm 0.21(10)$ & $16.0 \pm 2.5(9)$ & $66.43 \pm 146.06(9)$ \\
$08: 00$ & $0.02 \pm 0.01(8)$ & - & $12.05 \pm 11.33(4)$ \\
$09: 00$ & 0 & - \\
\hline
\end{tabular}

* In afternoon, the nectar is not produced.

When the petals open, the flower of $C$. brasiliense contains available nectar around the ovary (Gribel, 1986; Rocha et al., 1991; Baumgarten, 1994), therefore hummingbirds may act as nectar robbers. According to Endress (1994), trapliners establish foraging routes and fly long distances, accomplishing cross-pollination. Continuous nectar production at low sugar concentration favors the movement of glossophagine bats among flowers, due to the high energetic demands of these animals. It is possible that such characteristics pressure birds to visit a larger number of plants or remain for a longer period of time in the same individual. In this study, brief visits may have been of birds moving about, longer visits by birds visiting several flowers in the same plant. On the other hand, reduced frequency of time of visitation may be related to lesser dependence on the resource (Rojas \& Ribon, 1997).

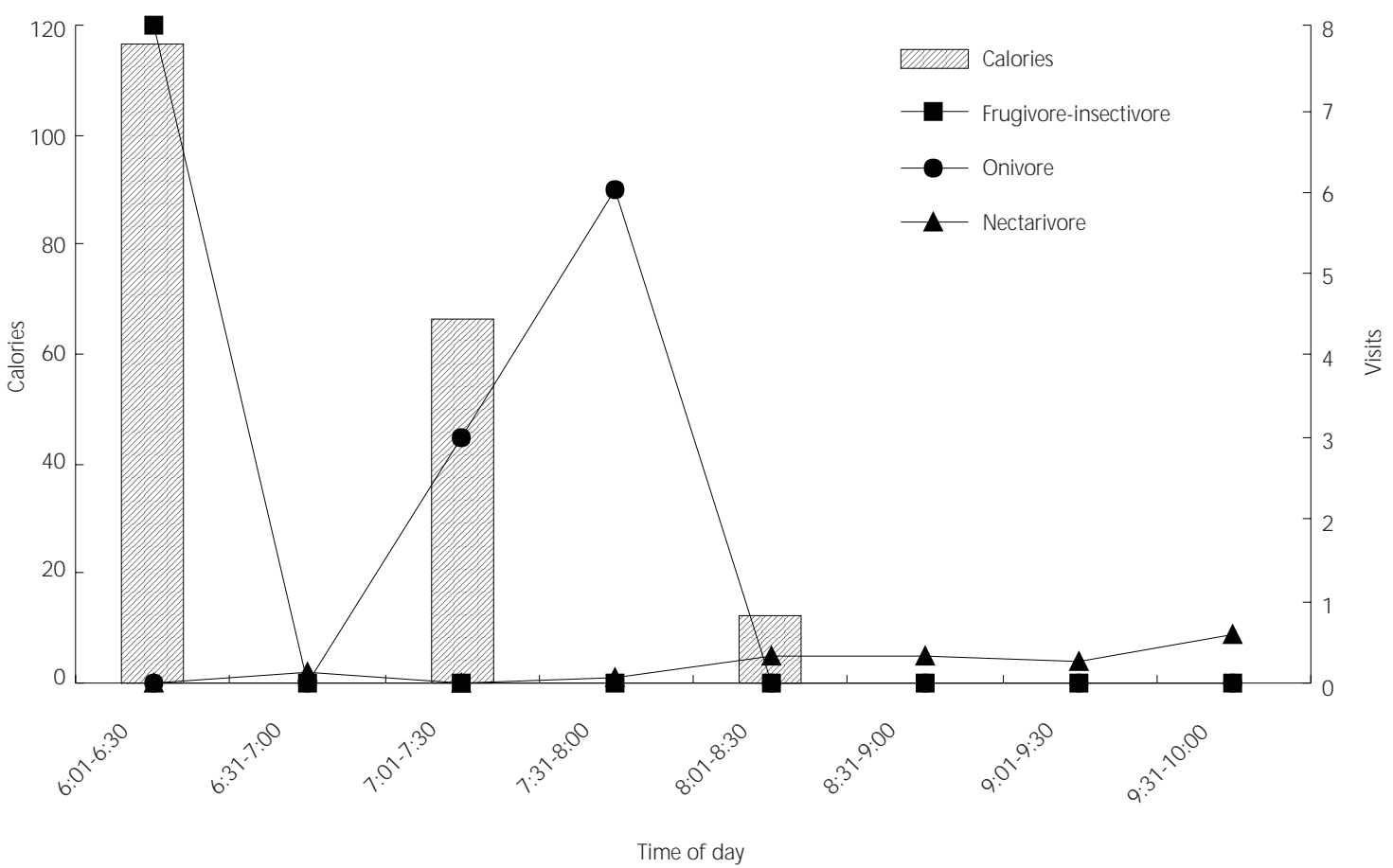

Fig. 1 - Mean number of visits and calories per flower of $C$. brasiliense in the morning. 


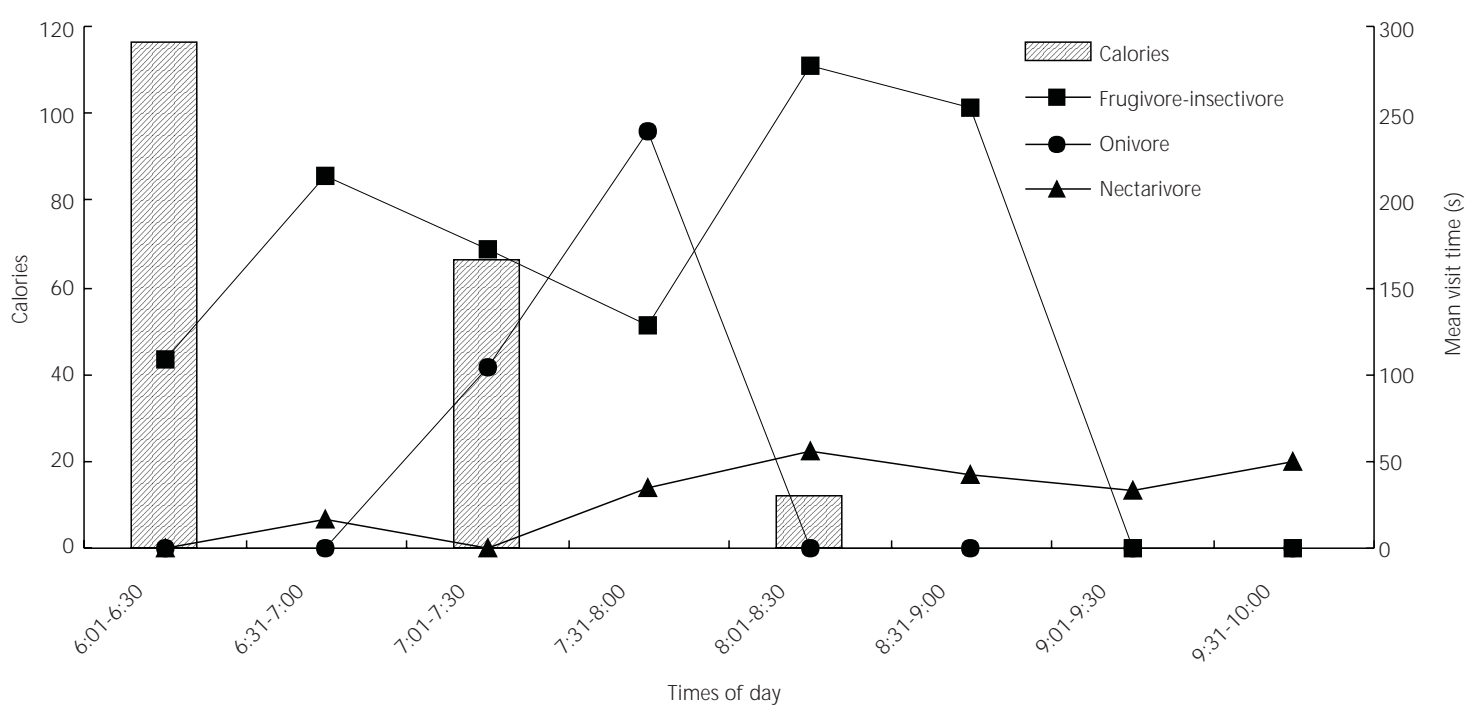

Fig. 2 - Mean visit time (seconds) and nectar offer in calories per flower of C. brasiliense.

Timing separation between non-nectarivores and nectarivores may be associated to importance and availability of the resource for each group. To non-nectarivores that exploit $C$. brasiliense between 6:00 and 8:00, nectar may represent an alternative resource when the main components of the diet are scarce. The fact that nectarivores forage for nectar between 8:00 and 10:00 may be the result of the availability of other sources of energy or insect diet in the early morning, or presence of larger birds at that time.

Use of nectar after the main caloric reward peak may be related to the late start of bird activity, and to the time necessary to detect the resource, or resources preferred elsewhere. After the plant stops nectar production, exploitation continues with use of residual nectar.

Gribel (1986) argues that diurnal pollination in $C$. brasiliense is improbable due to the small quantity of pollen available, the dry stigmatic surface and the evidence that pollinators do not touched it during the day. However, he emphasizes the possibility of pollination by Passeriformes. Inferences about diurnal pollination in $C$. brasiliense should only be considered after tests of diurnal receptivity of flowers. The function of a floral visitor ranges from unidirectional exploitation to mutualism, depending on the presence of other floral visitors (Arizmendi et al., 1996). If the inferences made by Gribel (1986) are confirmed, the relation between $C$. brasiliense and its diurnal visitors is exploitation.

The diversity of reproductive strategies found in cerrado communities may indicate that maintenance of the diversity of pollen-carriers may be dependent on spatial and temporal heterogeneity in the distribution of resources in the vegetation (Oliveira, 1994). C. brasiliense may be accomplishing the important function of offering resources for some components of the diurnal avifauna during shortages of their main resources, notably in the dry season.

Acknowledgments - I thank IBGE for logistical support, Helena C. Morais and Valéria Saracura for suggestions, Carlos E. R. Tomé and John David Bagnall for translating the original to English and Cinara Melo for help with grammar. I also thank colleagues and collaborators from the course in Field Methods in Ecology, offered by the Universidade de Brasília. Genilda M. de Oliveira, Miguel A. Marini, Paulo E. Oliveira and anonymous reviewers for their valuable comments. CNPq supported this work with grant 140840/ 99-0.

\section{REFERENCES}

ARAÚJO, A. C., 1996, Beija-flores e seus recursos florais numa área de planície costeira do litoral norte de São Paulo. Master Thesis. Universidade de Campinas, Campinas.

ARIZMENDI, M. C., DOMÍNGUEZ, C. A. \& DIRZO, R., 1996, The role of an avian nectar robbers and of hummingbird pollinators in the reproduction of plant species. Func. Ecol., 10: 119-127. 
BAUMGARTEN, J. E., 1994, Oferta de néctar e produção de frutos em uma população de Caryocar brasiliense Camb. (Caryocaraceae) num cerrado do DF. Master Thesis. Universidade de Brasília, Brasília.

ENDRESS, P. K., 1994, Diversity and evolutionary biology of tropical flowers. Cambridge University Press, Cambridge, $583 \mathrm{p}$.

FEINSINGER, P., SWARM, L. A. \& WOLFF, J. A., 1985, Nectar-feeding birds on Trinidad and Tobago: comparison of diverse and depauperate guilds. Ecol. Monog., 55: $1-28$.

FRISCH, J. D., 1981, Aves brasileiras. Dalgas-Ecoltec Ecologia Técnica e Comércio Ltda, São Paulo, 353p.

GRANTSAU, R., 1988, Os beija-flores do Brasil. Expressão e Cultura, Rio de Janeiro, 234p.

GRIBEL, R., 1986, Ecologia da polinização e da dispersão de Caryocar brasiliense Camb. (Caryocaraceae) na região do Distrito Federal. Master Thesis. Universidade de Brasília, Brasília.

GRIBEL, R. \& HAY, J. D., 1993, Pollination ecology of Caryocar brasiliense (Caryocaraceae) in Central Brazil cerrado vegetation. J. Trop. Ecol., 9: 199-211.
GUIX, J. C. \& RUIZ, X., 1998, Intensive folivory by Thraupis sayaca (Emberizidae: Thraupinae) in South-eastern Brazil. Ararajuba, 6: 138-140.

KEARNS, C. A. \& INOUYE, D. W., 1993, Techniques for pollination biologists. University Press of Colorado, Colorado, 583p.

OLIVEIRA, G. M., 1998, Disponibilidade de recursos florais para beija-flores num cerrado de Uberlândia, MG. Master Thesis. Universidade de Brasília, Brasília.

OLIVEIRA, P. E., 1994, Aspectos da reprodução das plantas de cerrado e conservação. Bot. Herb. Ezec. Paulo Heringer, 1: 34-45.

ROCHA, I. R. D., MORAIS, H. C. \& KITAYAMA, K., 1991, Visitantes diurnos de flores quiropterófilas. Rev. Brasil. Biol., 51: 249-256.

ROJAS, R. \& RIBON, R., 1997, Guilda de aves em Bowdichia virgilioides (Fabaceae, Faboideae) em área de cerrado de Furnas, Minas Gerais. Ararajuba, 5: 189-194.

SAZIMA, M. \& SAZIMA, I., 1975, Quiropterofilia em Lafoensia pacari St. Hill (Lythraceae), na Serra do Cipó, Minas Gerais. Ciên. e Cult., 27: 405-416. 